\title{
Aging population, bibliographic review
}

\section{Introduction}

Population aging is the increase in the number of older adults with respect to the population group they belong to, and this population group has gradually increased. The social challenge that this represents, is due to the needs generated from the economic, biomedical and social point of view. Cuba is at an advanced stage of aging, which is why policies and methods have been established with social medical projections that allow these people to feel more useful to family and society. ${ }^{1}$ The appropriate physical and mental exercise is a pillar to achieve an old age with adequate health because it positively compensates muscle mass, promotes respiratory dynamics, temperature, blood volume and improves peripheral resistance and the ability to respond to stress. Therefore, in order to raise the level of knowledge and sensitize health personnel about the importance of physical exercise in the health status of the elderly, the motivation to carry out this literature review arises. ${ }^{2}$

\section{Developing}

It is known that physical exercise provides the body a physiological activity in all tissues that slow the consequences of aging: Currently, physical activity and physical exercise are considered the best investment or the best business for achieving health published on a global scale. ${ }^{3}$ The movement in the life of the older adult is vital, the loss of walking capacity and balance indicate high risk to your health that is measured in terms of functional capacity and is evaluated by means of scales. Equilibrium disorders affect more than 50\% of the elderly is the most frequent complaint in people over 75 years with an estimated prevalence of $26.9 \%$. The frequency of mobility disorders increases with age, this situation causes progressive dependence and can finally cause partial or total immobility. ${ }^{4}$ For a successful aging it is vital the preservation of the march, because the Disorders in this sense limit activity, increase morbidity and dependence, a factor that contributes to the institutionalization and entry into nursing homes. Changes in gait and balance can be a predictor of future falls. ${ }^{5,6}$ The falls in the elderly are events of great interest in Geriatrics because of its high prevalence, constitute an important risk for fractures and are associated with a increase in mortality. They have as a complication the functional and psychological limitation resulting from the fear of falling. The health costs they generate are cause for concern, since the increase in life expectancy means that more people can suffer falls with disabling consequences. ${ }^{7,8}$ According to Cuban statistics, the main causes of death are the accidents, which occupy the fifth cause among people over 60 and Within the mortality by accidents, in this same age group, falls occupy the first place, which is why for our country it is so important to draw up strategies for its prevention. ${ }^{9}$

Gait and balance assessment is the most useful tool to identify patients with risk of falls. For this purpose there is clinical evaluation carried out through careful observation of a series of maneuvers, the application of scales and computerized instruments are also included. ${ }^{10}$ Rehabilitation, like any intervention, requires an instrument of evaluation to quantify objectively the degree of disability that presents a patient and monitor the changes produced with the treatment. The scales validated most used at present are: the Tinetti test, the test of "get up and walk", the Romberg test and the timed evaluation of the station unipodal; and the static objective methods: fixed force platforms; but
Volume 3 Issue I - 2019

\author{
Maisel Morejón Márquez,' Arialys Hernández \\ Gory, ${ }^{2}$ Armando Pujol Machín, ${ }^{3}$ Marcia \\ Falcon Díaz \\ 'Policlínico Iro de Enero, Consolación del Sur, Pinar del Río, \\ Cuba \\ ${ }^{2}$ Hospital Clínico Quirúrgico León Cuervo Rubio, Pinar del Río, \\ Cuba \\ ${ }^{3}$ Facultad de Ciencias Médicas, Pinar del Río, Cuba \\ ${ }^{4}$ Policlínico: I ro de Enero, Consolación del Sur, Pinar del Río, \\ Cuba
}

Correspondence: Maisel Morejón Márquez, Policlínico I ro de Enero, Consolación del Sur, Pinar del Río, Cuba, Email lizdany@infomed.sld.cu

Received: January 08, 2019 | Published: February 20, 2019

none of the clinical scales has therapeutic value in the correction of these disorders as the force platform (Cobs), which does not replace the clinical assessment but complements it and allows a better attention to the patients' problems..$^{11,12}$ The dynamometric platforms are systems of kinetic analysis of movement, allow to measure the forces that the foot exerts on the plane of support during the March, the race or the jump. The COBS can be used as a tool diagnostic and therapeutic or biomechanical gait studies. It allows to value different parameters of the walk objectively and effectively, appreciate the factors that can modify it and assess the effectiveness of the treatment. It is a repeatable, quantifiable, objective and reliable method. ${ }^{13,14}$ The CobsBiofeedback Platform (PCB) is an information response team and training that provides simple information, represented in graphic form, acoustic or both, in real time, on the movements of the body so fast and objective, showing the exact response of a person's motor skills, allowing effective planning and control of the therapy; It also allows qualitative and quantitative evaluation of motor skills: balance, load capacity, strength, coordination, speed; In addition, other abilities that influence motor skills can be proven, such as: body perception, proprioception, cognition, attention, reaction, anticipation, visual and acoustic perception. In this way you can offer a customized program for people of the elderly in order to prevent falls. ${ }^{15,16} \mathrm{Cuba}$ is at an advanced stage of the demographic transition, with a low fertility rate and declining mortality. It is considered one of the oldest (18.3\%) in the Americas; by 2020 around 400,000 Cubans will have reached the age of $80 . \cdot^{17,18}$ It is not estimated that by 2025 Cuba will be the oldest country in Latin America and by 2050, one of the oldest in the world. ${ }^{9}$ Roig Hechavarría ${ }^{19}$ concluded in his study that older adults who attended the homes of grandparents of the Holguín municipality, mostly did not show cognitive impairment, nor did they show psychoaffective alteration. It must be remembered that in these institutions physical exercise is a fundamental pillar. The author refers that reconocer, evaluates and treats balance problems that occur in older adults and develop care strategies, is a priority of health in the territory.

\section{Acknowledgments}

None.

\section{Conflicts of interest}

The author declares there is no conflict of interest. 


\section{References}

1. Tabio Henry YE, Rubido Gómez D, López Lorenzo ME. Social risk factors in the elderly. Infociencia Magazine. 2011;15(3).

2. Huenchuan S. The protection of health within the framework of demographic dynamics and rights. Santiago de Chile. 2018.

3. Mirabal Florín N. General foundations of Physical Education. In: Mirabal Florín N et al., editors. Theory and methodology of Physical Education for the EPEF. Havana: Editorial Sports. 2011;11-14.

4. Alonso Galván P, SansóSoberats FJ, Díaz-Canel Navarro AM, et al. Envejecimiento poblacional y fragilidad en el adulto mayor. Rev Cubana Salud Public. 2012;33(1):1-17.

5. Reyes Torres I CHJ. A healthy and active human aging process, a challenge for elderly, family and society. Cuban Invest Magazine Bioméd. 2011;30(3).

6. Alfonso Carmen R. Posture and balance of the old man. Rev AdultsHealth Life. 2012;10(1):1-12.

7. American Geriatrics Society Expert Panel on the Care of Older Adults with Multimorbidity. Patient-centered care for older adults with multiple chronic conditions: a stepwise approach from the American Geriatrics Society: American Geriatrics Society Expert Panel on the Care of Older Adults with Multimorbidity. J Am Geriatr Soc. 2012;60(10):1957-1968.

8. Kane RL, Shamliyan T, Talley K, et al. The association between geriatric syndromes and survival. J Am Geriatr Soc. 2012; 60(5):896-904.

9. Cuba. Ministry of Public Health. National Bureau of Statistics. An uario Health Statistics; 2017.
10. Rodríguez Montalbán MGRO, Hernández Silva T, Echavarría Danger $\mathrm{S}$, et al. Morbidity due to movement disorders in the Neurology department. MEDISAN. 2012;16(5).

11. Vicente E, Rodríguez A, Sánchez E, Quintana L. Diagnosis and Treatment in Internal Medicine. ECIMED. 2011;2(94):694-703.

12. Collado Vázquez S. Dynamometric platforms. Applications. Journal of the Faculty of Health Sciences. 2012;3:1-18.

13. Collado Vázquez S. Methods of study of the march. In: Collado Vázquez S et al., editors. Motricity Fundamentals and applications. Madrid: Dykinson. 2011; p. 281-288.

14. Collado S. Analysis of the human march with Dinamometric Platforms. Influence of cargo transport. Madrid: Faculty of Medicine of the Complutense University. 2012.

15. COBS Platform Digital publication. 2012;28(6):655-659.

16. Physiomed website. Cobs Platform.

17. Baster Moro JC. Medical and social care to the older adult in Holguin province. Rev Cubana Salud Pública. 2011;37(3):207-218.

18. Santiesteban Pérez I, Mateo Arce CI, Pérez Ferrás ML. The older adult, the family and the community. Medical Scientific Mail of Holguín. 2011;12(3).

19. Roig Hechavarría C, Vega Bonet V, Ávila Fernández E, et al. Aplicación de terapia cognitivo conductual para elevar la autoestima del adulto mayor en Casas de abuelos. Correo CientMed Holguín. 2011;15(2). 